\title{
PENGARUH PEMBERIAN LAYANAN KONSELING KELOMPOK PENDEKATAN RATIONAL EMOTIVE THERAPHY TEKNIK LIVE MODEL TERHADAP KECEMASAN KARIR MAHASISWA BK REGULER A 2015
}

\author{
Wulan Maulidya \\ Dra. Zuraida Lubis, M.Pd.Kons \\ Jurusan Psikologi Pendidikan dan Bimbingan, Fakultas Ilmu Pendidikan \\ Universitas Negeri Medan
}

\begin{abstract}
Abstrak
Tujuan penelitian ini adalah untuk mengetahui pengaruh konseling kelompok pendekatan Rational Emotive Theraphy teknik Live Model terhadap tingkat kecemasan karir pada mahasiswa bimbingan dan konseling kelas Reguler A 2015 Universitas Negeri Medan Tahun Ajaran 2016/2017. Subjek dalam penelitian ini adalah mahasiswa BK Reguler A 2015 yang berjumlah 7 orang. Pengambilan sampel dilakukan mengunakan purposive sampling. Teknik pengumpulan data dalam penelitian ini adalah menggunakan angket yang di sebar kemudian di analisis dengan metode menggunkan uji Wilcoxon. Hasil analisis data yang diperoleh dalam penelitian ini adalah nilai $J_{\text {hitung }}=3$ dengan $\alpha=0,05$ dan $n=7$, maka berdasarkan daftar, $J_{\text {tabel }}=2$ Dengan demikian $J_{\text {hitung }}>J_{\text {tabel }}(3>2)$. Artinya hipotesis diterima. Data pre-test di peroleh rata-rata 120,42, sedangkan setelah pemberian konseling kelompok pendekatan Rational emotive Theraphy teknik Live Model (post-test) diperoleh rata-rata 171,28 artinya skor rata-rata mahasiswa setelah mendapatkan layanan konseling kelompok pendekatan Rational emotive Theraphy teknik Live Model lebih tinggi dari pada sebelum mendapatkan layanan konseling pendekatan Rational emotive Theraphy teknik Live Model yang mana artinya tingkat kecemasan karir mahasiswa tersebut berkurang. Perubahan penurunan tingkat kecemasan karir mahasiswa setelah diberikan layanan konseling kelompok pendekatan Rational emotive Theraphy teknik Live Model sebesar 42,23\%. Hal ini menunjukan bahwa ada pengaruh pemberian layanan konseling kelompok pendekatan Rational emotive Theraphy teknik Live Model terhadap tingkat kecemasan karir mahasiswa BK Reguler A 2015 Universitas Negeri Medan Tahun Ajaran 2016/2017 atau hipotesis dapat di terima.
\end{abstract}

Kata Kunci : Konseling Kelompok, Teknik Live Model, Kecemasan Karir Mahasiswa

\section{Abstrack}

The purpose of this research is to find out The Infuence of Group Counseling Approach of Rational Emotive Therapy Techniuques Live Models to Career Anxiety of Student BK Reguler A 2015 At State University of Medan Acaemik year 2016/2017. The research was conducted at State University of Medan in the Faculty of Science Education. The type of this research is Quasi Ekperimental. Subject in this research are Students of BK Reguler A 2015 that amounted to 7 people, sampling is done by using purposive sampling. data collection techniques in this study using a dispersed questionnaire and then analyzed by using wilcoxon test. The result of analysis data from this research is $J_{\text {calculate }}=3$ with $\alpha=0,05$ and $n=7$ ten based on the list $J_{\text {tabel }}$ $=2$. Then $J_{\text {calculate }}>J_{\text {tabel }}(3>2)$ means that the hypothesis is accepted. Data of pre-test obtaine by the average 120,42 while after given Group Counseling Approach of Rational Emotive Therapy Techniuques Live Models (post-test) obtained an average of 171,28. That is the average score of the students after getting Group Counseling Approach of Rational Emotive Therapy Techniuques Live Models is higer than before getting Group Counseling Approach of Rational Emotive Therapy Techniuques Live Models. Which means that the level of career anxiety students is reduced. Cahanges in decreas of career anxiety students after being given Group Counseling Approach of Rational Emotive Therapy Techniuques Live Models is by 42,23\%. This suggests that there is any Infuence of Group Counseling Approach of Rational Emotive Therapy Techniuques Live Models to Career Anxiety of Student BK Reguler A 2015 At State University of Medan Acaemik year 2016/2017or the Hypothesis is Accepted.

Key word : Group Counseling, Techniuques Live Models, Career Anxiety of Students

PENDAHULUAN

Karir merupakan topik hangat yang banyak diperbincangkan oleh orang-orang dan merupakan masalah yang sangat serius. Tidak seimbangnya antara jumlah lowongan kerja yang ada dengan jumlah 
lulusan atau tamatan pelajar yang telah menyelesaikan pendidikannya menjadikan hal ini masalah yang sangat serius, terbukti dengan masih sangat tingginya angka pengangguran yang ada di Indonesia ini .

Berdasarkan Badan Pusat Statistik per 2013 lalu, terdapat 7,9 juta jiwa pengangguran yang ada di Indonesia ini, hal ini membuktikan bahwa masih sangat minimnya jumlah lowongan pekerjaan yang ada di Indonesia ini, dan karena hal itulah sangat banyak mahasiswa yang kini mulai khawatir atau cemas dengan nasib masa depan karir mereka. Mereka cemas jika mereka tidak mendapatkan pekerjaan yang sesuai dengan keinginan ataupun sesuai jurusan yang mereka tempuh. Berdasarkan penelitian terdahulu yang dilakukan oleh Rahmasari pada tahun 2016 lalu terhadap mahasiswa BK di di UIN Walisongo Semarang menunjukkan bahwa dari 55 mahasiswa yang dijadikan sampel, 54 di antaranya mengalami kecemasan karir dengan presentse di atas $50 \%$.

Selain itu keputusan Presiden republik Indonesia nomor 37 tahun 2014 tentang komite nasional persiapan pelaksanaan masyarakat ekonomi association of southeast asian nations ( MEA) yang mengizinkan regulasi arus tenaga kerja dari negara manapun dengan bebas mencari pekerjaan di Indonesia telah menyebabkan kecemasan di kalangan mahasiswa terutama karena setelah tamat nanti untuk mendapat pekerjaan mereka tidak hanya harus bersaing dengan sesama warga Indonesia saja, tetapi juga dengan warga negara asing yang memiliki SDM yang lebih berkualitas.

Berdasarkan hasil pengamatan peneliti saat melakukan observasi di Fakultas Ilmu Pendidikan Universitas Negeri Medan khususnya Bimbingan Konseling, banyak mahasiswa yang khawatir dengan masa depan karir mereka yaitu dari 23 mahasiswa 13 diantaranya mengalami hal tersebut. Banyak diantara mereka yang cemas tidak akan mendapatkan pekerjaan setelah mereka lulus kuliah nanti. Kecemasan ini disebabkan oleh kurangnya rasa percaya diri mereka dalam menghadapi persaingan yang ada dalam dunia pekerjaan.

Seharusnya masalah kecemasan karir ini dapat dicegah sejak awal yaitu dengan cara mengikuti bimbingan konseling karir yang ada di sekolah menengah pertama dan sekolah menengah akhir yang dilakukan oleh guru BK yang ada di sekolah tersebut, akan tetapi pada kenyataannya dilapangan, sangat sedikit 
guru BK yang melakukan bimbingan konseling karir ini.

Sebagai seorang calon guru BK yang nantinya akan membantu siswa-siswa disekolah untuk mengatasi permasalahan mereka, mahasiswa-mahasiswa BK ini harus terlebih dahulu menyelesaikan masalah pribadi mereka, salah satunya adalah masalah kecemasan terhadap karir masa depan mereka. Mereka harus bisa menghilangkan kecemasan tersebut dan mulai mempersiapkan diri mereka untuk menghadapi persaingan yang berat dalam dunia karir dengan cara lebih mengasah kopetensi dan kepercayaan diri mereka.

Pemecahan masalah individu sendiri akan dilakukan dengan cara merubah pemikiran irasional mereka tentang cemas tidak mendapak pekerjaan setelah lulus kuliah melalui beberapa contoh model hidup yang berlatar belakang sama maupun berbeda dari latar beakalang mereka. Keunggulan teknik live model sendiri adalah dengan menunjukkan atau memperlihatkan kepada mereka bahwa jika orang lain mampu melakukannya, maka mereka juga pasti mampu melakukannya.

Maka dari itu peneliti merasa perlu untuk melakukan penelitian terhadap kecemasan karir mahasiswa melalui pemberian layanan konseling kelompok dengan pendekatan rasional emotif terapi teknik live model khususnya untuk mahasiswa BK reguler A 2015 Universitas Negeri Medan.

\section{KAJIAN PUSTAKA}

\section{Konseling Kelompok}

Menurut Pauline Harrison dalam Edi Kurnanto (2013: 7) konseling kelompok adalah konseling yang terdiri dari $4-8$ konseli yang bertemu dengan 1-2 konselor, yang dalam prosesnya konseling kelompok dapat membicarakan beberapa masalah, seperti kemampuan dalam membangun hubungan dan komunikasi, pengembangan harga diri, dan keterammpilan-keterampilan dalam mengatasi maslalah.

Juntika Nurihsan dalam Edi Kurnanto (2013 : 7) mengatakan bahwa konseling kelompok adalah suatu bantuan kepada individu dalam situasi kelompok yang bersifat pencegahan dan penyembuhan, serta diarahkan pada pemberian kemudahan dalam perkembangan dan pertumbuhannya. Sedangkan menurut Gazda dalam Ngurah Adiphutra (2015 : 24) konseling kelompok merupakan suatu sistem layanan bantuan yang amat baik untuk membantu pengembangan kemampuan pribadi, pencegahan, dan menangani konfik-konfik antar pribadi atau pemecahan masalah. 
Berdasarkan beberapa pendapat di atas dapat disimpulkan bahwa konseling kelompok adalah proses pemberian bantuan kepada individu dengan memanfaatkan situasi kelompok yang dinamis untuk memfasilitasi perkembangan individu atau membantu individu dalam mengatasi masalah yang dihadapinya secara bersama-sama dan juga untuk membangun kemampuan dalam hubungan dan komunikasi, pengembangan harga diri, dan keterammpilan-keterampilan dalam mengatasi maslalah.

\section{Pendekatan Rational Emotive Theraphy}

Teori RET didasarkan pada satu prinsip bahwa emosi dan penalaran pikiran dan perasaan merupakan satu jalinan yang rumit di dalam diri (psikis) individu, serta bersumber pada keyakinan bahwa semua manusia normal berfikir, merasa, dan bertindak secara stimulan. Pikiran mempengaruhi dan seringkali menciptakan perasaan dan perilaku, emosi mempengaruhi pikiran dan tindakan, dan tindakan mempengaruhi pikiran dan perasaan. Oleh karena itu, untuk mengubah salah satu aspek dari tiga aspek tersebut harus memodifikasi satu atau dua aspek yang lain (Adiphutra, 2015 : 136).

Selanjutnya Latipun dalam Namora Lumongga (2011:178) juga menerangkan bahwa ada tiga istilah yang terkait dengan tingkah laku manusia berdasarkan pandangan Rational Emotif Theraphy yaitu : Antasedent Event (A), Belief (B), dan Emotional Consequence (C). Istilahistilah ini lebih dikenal dengan konsep AB-C, berikut ini adalah penjelasannya. (a). Antacedent Event (A) adalah peristiwa, fakta, perilaku, atau sikap orang lain yang terjadi di dalam maupun luar diri individu. Misalnya perceraian orangtua atau kelulusan bagi siswa. (b). Belief (B) adalah keyakinan dan nilai individu terhadap suatu peristiwa. Keyakinan atas dua bagian yaitu : pertama, keyakinan rasional $(\mathrm{rB})$ yang merupakan keyakinan yang tepat, masuk akal, dan produktif. Kedua, keyakinan irasional (iB) yang merupakan yang salah, tidak masuk akal, emosional, dan tidak produktif. Keyakinan dapat berasal dari nilai agama, norma masyarakat, dan aturan orangtua. (c). Emotional consequence (C) adalah konsekuensi emosional baik berupa senang atau hambatan emosi yang diterima individu sebagai akibat reaksi dalam hubungan dengan antacedent event. Konsekuensi emosional ini bukanlah akibat langsung dari $\mathrm{A}$, tetapi juga $\mathrm{B}$ baik dipengaruhi oleh iB maupun $\mathrm{rB}$ individu. Misalnya sedih, marah, bahagia, dan bangga. 
Jika teori A-B-C ini dilihat dari permasalahan tingkat kecemasan karir mahasiswa, dapat kita implementasikan bahwa yang menjadi A (Antasedent Event) adalah tingginya tingkat persaingan di dalam dunia karir dan juga ketidak siapan para mahasiswa untuk menghadapi persaingan di dalam dunia karir tersebut. Dan yang menjadi B (Belief) adalah para mahasiswa menganggap bahwa mereka tidak memiliki keahlian di bidang yang mereka geluti ataupun mereka menganggap bahwa orang lain lebih hebat dari mereka. Dan yang menjadi C (Emotional consequence) adalah karena adanya A dan B maka muncul lah perasaan tidak percaya diri dan gelisah di dalam diri mereka sehingga menyebabkan mereka mengalami kecemasan karir.

\section{Teknik Live Model}

Menurut Bradley (2015: 340) Modeling adalah proses bagaimana individu belajar dari mengamati orang lain. Ia adalah salah satu komponen teori belajar sosial yang dikembangkan oleh Alberd Bandura (2006) dan telah menjadi salah satu intervensi pelatihan berbasis psikologi yang paling luas digunakan, paling banyak diteliti, dan sangat dihormati. Modeling juga disebut sebagai imitasi, identifikasi, belajar observasional, dan vicarious learning.

Penelitian awal tentang modeling dilaksanakan oleh Miller dan Dollard (1941) yang menemukan bahwa, melalui reinforcement (penguatan, partisipan dapat belajar untuk meniru sebuah model, belajar untuk tidak meniru model yang lain, belajar untu membedakan kedua model, dan menggeneralisasikan diskriminasi meniru atau tidak meniru perilaku pada orang-orang lain yang serupa.

Hackney \& Cormier dalam Bradley (2015:340) menyatakan bahwa ada beberapa tipe dasar modeling yaitu, Overt modelling atau live modeling dan symbolic modeling. Live model terjadi ketika satu orang atau lebih mendemonstrasikan perilaku yang akan dipelajari yang menjadi live model bisa termasuk konselor profesional, guru atau teman sebaya klien. Menurut Bradley (2015) secara umum live modeling tampaknya lebih efektif dalam mengajarkan keterampilan emosional dan sosial. Menurut Kiswantoro (2015) implementasi model konseling ini terdiri empat tahap, yaitu sebagai berikut :

1. Tahap pembentukan.

Tahap ini merupakan tahap pengenalan dan perlibatan dari anggota untuk mempererat kesatuan dalam 
kelompok dengan bertujuan agar anggota memahami tujuan atau harapan-harapan yang ingin dicapai dalam konseling kelompok. Kendali kepemimpinan dipegang pimpinan kelompok. Tahap ini bertujuan untuk menumbuhkan suasana saling mengenal, percaya, menerima, dan membantu teman-teman yang ada dalam kelompok. Kegiatan yang dilakukan pada tahap ini adalah mengungkapkan pengertian dan tujuan kegiatan kelompok dalam rangka pelayanan konseling kelompok; menjelaskan cara-cara dan asas kegiatan kelompok, anggota kelompok saling memperkenalkan diri dan mengungkapkan diri. Pada tahap ini diselingi dengan permainan dengan melibatkan pemimpin kelompok sebagai live model agar terjadi suasana semakin akrab dari para anggota kelompok.

2. Tahap peralihan.

Tahap ini merupakan tahap transisi dari tahap pembentukan ke tahap kegiatan. Dalam menjelaskan kegiatan apa yang akan dilaksanakan pemimpin kelompok dapat menegaskan jenis kegiatan konseling kelompok. Setelah jelas kegiatan apa yang harus dilakukan maka muncul kesiapan anggota dalam melaksanakan kegiatan dan setiap anggota kelompok tahu manfaat yang akan diperoleh. Agar konseling kelompok berjalan lancar, pemimpin kelompok dengan gaya kepemimpinannya pada tahap ini membawa anggota kelompok untuk tertarik mengikuti tahap selanjutnya, dengan menguraikan kembali tujuan kegiatan kelompok, asas kerahasiaan, kesukarelaan, keterbukaan, kekinian dan sebagainya.

3. Tahap Kegiatan

Tahap ini merupakan tahap inti dari kegiatan konseling kelompok dengan terjadinya suasana dinamika kelompok dan terbahasnya secara tuntas permasalahan yang dihadapi oleh anggota kelompok, saling tukar pengalaman dan terciptanya suasana untuk mengembangkan diri, baik yang menyangkut pengembangan kemampuan berkomunikasi maupun menyangkut pendapat yang dikemukakan oleh kelompok secara bebas. Pada tahap ini pemimpin kelompok mengemukakan topik untuk dibahas oleh kelompok,. Pemimpin kelompok sebagai live model memberi stimulasi kepada anggota kelompok, sehingga anggota kelompok dapat menceritakan permasalahannya tentang hal-hal yang belum jelas menyangkut topik yang dikemukakan pemimpin kelompok. Pemimpin kelompok sebagai Live model dapat menanggapi dan berbagi pengalaman 
dengan anggota kelompok. Selanjutnya anggota kelompok membahas topik tersebut secara mendalam dan tuntas.

\section{Tahap Pengakhiran}

Pada tahap ini merupakan tahap akhir dalam konseling kelompok yaitu penyimpulan hasil pembahasan permasalahan dan anggota kelompok mendapatkan penguatan hal-hal yang telah dipelajari. Pada tahap ini terdapat dua kegiatan yaitu penilaian dan tindak lanjut. Tahap ini merupakan tahap penutup dari serangkaian kegiatan konseling kelompok karena telah tuntasnya topik yang dibahas oleh kelompok tersebut. Dalam kegiatan kelompok berpusat pada pembahasan dan penjelasan tentang kemampuan anggota kelompok untuk menetapkan hal-hal yang telah diperoleh melalui layanan konseling kelompok dalam kehidupan sehari-hari. Oleh karenanya pemimpin kelompok sebagai live model berperan memberikan penguatan (reinforcement) terhadap hasilhasil yang telah dicapai kelompok tersebut. Pemimpin kelompok mengemukakan bahwa kegiatan akan segera diakhiri; pemimpin kelompok sebagai live model dan anggota kelompok mengemukakan kesan dan hasil-hasil kegiatan, membahas kegiatan selanjutnya, kemudian mengemukakan pesan dan harapan.

\section{Defenisi Kecemasan}

Kartono (1992) mendefinisikan kecemasan sebagai semacam kegelisahan, kekhawatiran dan ketakutan terhadap sesuatu yang tidak jelas atau kabur, dapat berupa perasaan campuran berisikan ketakutan dan keprihatinan mengenai masa-masa mendatang tanpa sebab khusus untuk ketakutan tersebut. Begitu juga dengan Hurlock (1996), mengatakan bahwa kecemasan merupakan suatu kekhawatiran umum mengenai suatu peristiwa yang tidak jelas atau tentang peristiwa yang akan datang. Tanda-tanda yang biasanya muncul berupa perasaan khawatir, gelisah dan perasaan-perasaan yang kurang menyenangkan. Biasanya disertai oleh rasa kurang percaya diri, tidak mampu, merasa rendah diri serta tidak sanggup untuk menyelesaikan masalah, dan apabila seseorang menghadapi suatu masalah atau situasi konflik ia akan meragukan kemampuan dirinya dalam mengatasi masalah dan kesulitannya tersebut karena dia akan merasa kurang mampu bila dibandingkan dengan orang lain.

Chaplin (1997), merumuskan hal yang sama bahwa kecemasan atau kegelisahan sebagai suatu perasaan kekhawatiran dan ketakutan menghadapi situasi yang akan datang tanpa sebab 
khusus untuk ketakutan tersebut, disertai dengan gejala-gejala fisik seperti berkeringat dingin, gemetar, usaha melarikan diri dan lain-lain.

Maramis (1998), menambahkan bahwa komponen kecemasan adalah jantung berdebar, nyeri pada dada, tukak lambung, sakit kepala, gangguan tidur dan sesak napas. Kecemasan adalah kondisi emosional kronis yang kompleks dengan komponen utama rasa takut dan merupakan ciri dari berbagai penyimpangan atau kelainan syaraf dan mental.

Dari penjelasan di atas dapat ditarik kesimpulan bahwa kecemasan adalah perasaan khawatir yang dialami seseorang ketika mengalami hal-hal yang dianggap sebagai suatu hambatan, ancaman, keinginan pribadi serta suatu peristiwa yang akan datang.

Greenberger dan Padesky (1995) mengelompokkan kecemasan menjadi empat aspek, yaitu :

\section{a. Reaksi fisik}

Reaksi fisik yang terjadi pada orang yang cemas meliputi telapak tangan berkeringat, otot tegang, jantung berdebardebar (berdegup kencang), pipi merona, pusing-pusing dan sulit bernafas ketika seseorang menghadapi situasi yang membuat dirinya merasa cemas. b. Pemikiran

Orang yang cemas biasanya memikirkan bahaya secara berlebihan, menganggap dirinya tidak mampu mengatasi masalah, tidak menganggap penting bantuan yang ada dan khawatir serta berpikir tentang hal yang buruk. Seseorang yang cemas cenderung memiliki pemikiran-pemikiran yang negatif mengenai mampu tidaknya ia dalam berusaha menghadapi situasi yang membuat dirinya merasa cemas. Biasanya pemikiran ini akan menetap cukup lama, jika tanpa adanya usaha dari individu tersebut untuk merubah pemikirannya menjadi sesuatu yang lebih positif. Pemikiran dapat berupa perasaan tidak mampu, merasa tidak memiliki keahlian, tidak siap dan sebagainya.

c. Perilaku

Orang yang cemas akan berperilaku menghindari situasi saat kecemasan itu terjadi, orang tersebut akan meninggalkan situasi ketika kecemasan mulai terjadi dan mencoba melakukan banyak hal secara sempurna dan mencoba mencegah bahaya.

d. Suasana Hati

Suasana hati orang yang cemas meliputi perasaan gugup, jengkel, cemas dan panik. Suasana hati juga dapat berubah secara tiba-tiba ketika seseorang dihadapkan pada kondisi yang 
memunculkan kecemasan tersebut. kehidupannya, sedangkan yang lain Perasaan gugup dan panik dapat mungkin memiliki rangkaian okupasimemunculkan kesulitan dalam okupasi yang begitu berbeda. Beaumont, memutuskan sesuatu, misalnya dalam hal keinginan dan minat.

Jadi aspek-aspek kecemasan adalah reaksi fisik, pemikiran, perilaku dan suasana hati.

\section{Karir}

Karir yang identik dengan pekerjaan dipahami secara bragam oleh banyak pihak. Bruce dan Shertzer (Irham\&Novan, 2014 : 200) memahami karir sebagai suatu rangkaian pekerjaan, jabatan, atau kedudukannya yang dimiliki seseorang selama hidupnya. H.L Wilensky (Irham \& Novan, 2014 : 200) memahami karir sebagai riwayat pekerjaan yang teratur dimana dalam setiap pekerjaan yang ditekuni selalu ada persiapan untuk waktu berikutnya atau masa depannya. Oleh sebab itu karir pada dasarnya berbicara tentang perjalanan hidup seseorang, bukan hanya masa bekerja, melainkan saat mereka menempuh pendidikan atau sekolah.

Tolbert dalam Manrihu (1988) menerangkan karir adalah sekuensi okupasi-okupasi dimana seseorang ikut serta di dalamnya, beberapa orang mungkin tetap berada di okupasi yang sama sepanjang tahap-tahap Cooper, Stockard (Manrihu, 1988) memberikan batasan bahwa karir adalah totalitas pekerjaan yang seseorang kerjakan selama hidupnya. Tetapi defenisi yang paling sering digunakan adalah jalannya peristiwa-peristiwa kehidupan, sekuensi okupasi-okupasi dan perjalanan kehidupan lainnya yang keseluruhannya menyatakan tanggung jawab seseorang kepada pekerjaan dalam keseluruhan pola perkembangan dirinya, serangkaian posisi-posisi yang diberi upah atau tidak berupah yang diduduki oleh seseorang sejak remaja sampai pensiun, yang mana okupasinya hanya satu mencakup peranan-peranan yang berkaitan dengan pekerjaan seperti misalnya mereka sebagai pelajar, kariawan, dan pensiunan bersama-sama dengan peranan-peranan pelengkap seperti kesenangan yang berkaitan dengan keluarga, dan kewarganegaraan. Karirkarir hanya ada jika orang-orang mengejarnya, karir-karir berpusat pada pribadi (person centered) (Super dalam Manrihu : 1988)

Pengertian karir tersebut menunjukkan bahwa setiap waktu dan setiap posisi seseorang, baik itu sekolah 
dari sekolah dasar, menengah perguruan tinggi, bahkan sampai bekerja dalam beberapa bidang dan posisi jabatan merupakan pengertian dari karir itu sendiri. Pembahasan karir tidak bisa lepas dari problematika karir. Problematika karir yang sering dihadapi adalah ketidak tahuan peserta didik atau bahkan setiap orang tentang apa yang akan dan harus dilakukan. Minimnya tentang gambaran tentang apa yang akan dilakukan merupakan sumber permasalahan karir yang dialami peserta didik, baik siswa maupun mahasiswa (Irham\&Novan, 2014:200).

\section{METODE PENELITIAN}

Jenis penelitian ini adalah eksperimen semu yaitu penelitan yang memberikan perlakuan atau tindakan kepada sekelompok orang atau subjek penelitian dengan pendekatan kuantitatif. Adapun desain dalam penelitian ini menggunakan pre-test dan post-test group.

Subjek penelitian ini adalah 7 orang mahasiswa BK reguler A stambuk 2015 UNIMED teknik purposive sampling, dengan rincian 4 orang mahasiswa memiliki tingkat kecemasan karir tinggi, 1 sedang, dan 2 orang rendah. Alasan pemilihan sampel engan tingkat kecemasan karir yang berbeda adalah diharapkan anggota yang memiliki tingkat kecemasan karir sedang dan renah dapat memberikan solusi ataupun pendapatnya tentang kecemasan karir yang dialami oleh anggota kelompok yang memiliki tingkat kecemasan karir tinggi. Hal ini bertujuan agar konseling kelompok dapat berjalan dengan menggunakan dinamika kelompok dan permasalahan anggota kelompok dapat diselesaikan dengan sesama teman kelompok. Dengan pengelompokan seperti ini diharakan tingkat kecemaan karir mahasiswa akan berkurang, sehingga tujuan dari konseling kelompok pendekatan Rational Emotive Theraphy teknik Live Model akan tercapai yaitu ada pengaruh yang signifikan Pemberian Layanan Konseling Kelompok Pendekatan RET Teknik live model Terhadap tingkat kecemasan karir Mahasiswa BK Reguler A 2015 di FIP UNIMED T.A $2016 / 2017$.

Untuk memperoleh jawaban atas permasalahan dalam penelitian, diperlukan data valid. Hal tersebut akan memberikan nilai yang benar sebagai kesimpulan akhir dari suatu penelitian. Instrumen pengumpulan data yang digunkan untuk penelitian ini dalah angket kuesioner kecemasan karir yang telah valid dan reliable.

HASIL DAN PEMBAHASAN 
Sebelum dilaksanakan layanan konseling kelompok pendekatan Rational Emotive Theraphy teknik Live Model, tingkat kecemasan karir mahasiswa BK Reguler A 2015 tergolong cukup tinggi. Hal ini dibuktikan dari hasil angket dimana skor mahasiswa menunjukan bahwa tingkat kecemasan karir mahasiswa yang cukup tinggi. Dalam hal ini peneliti menggunkan layanan konselin kelompok pendekatan Rational Emotive Theraphy teknik Live Model untuk mengatasai hal tersebut.

Berdasarkan perhitungan analisis deskriptif, dapat diketahui bahwa sebelum diberikan konseling kelompok pendekatan Rational Emotive Theraphy teknik Live Model, gambaran tingkat kecemasan karir mahasiswa tersebut adalah dari dua puluh mahasiswa yang dijadikan sampel secara umum dimana terlihat 4 orang mahasiswa termasuk dalam kategori tinggi, 10 orang mahasiswa kategori sedang dan 6 orang mahasiswa memiliki tingkat kecemasan karir dalam kategori tinggi. Karakteristik yang ditunjukan seperti rendahnya kepercaan diri mahasiswa dengan membanding-bandingkan dirinya dengan orang lain, selalu berpikiran negatif tentang dirinya.

Dari hasil analisis pre-test yang didapat melalui angket kecemasan karir di kelas BK Reguler A 2015 Unimed dari 7 mahasiswa yang dijadikan sampel penelitian terdapat 4 mahasiswa yang memiliki tingkat kecemasan karir yang tinggi, 1 mahasiswa dengan tingkat kecemasan karir sedang, dan 2 mahasiswa dengan tingkat kecemasan karir yang rendah. Dan dari hasil post test didapat 2 mahasiswa dengan tingkat kecemasan karir sedang dan 5 mahasiswa dengan tingkat kecemasan karir yang rendah. Dari penjelasan di atas, dapat kita lihat bahwa telah terjadi penuruanan tingkat kecemasan karir mahasiswa BK Reguler A 2015 UNIMED dimana sebelum diberikan layanan konseling kelompok pendekatan RET teknik live model mahasiswa yang memiliki tingkat kecemasan karir yang tinggi sebnayak 4 orang, sedang 1 orang dan rendah 2 orang setelah diberikan layanan konseling kelompok pendekatan RET teknik live model menjadi 2 orang mahasiswa memiliki tingkat kecemasan karir yang sedang dan 5 mahasiswa memiliki tingkat kecemasan karir yang rendah. Peningkatan tersebut juga dapat dilihat dari perbandingan rata-rata mahasiswa tersebut sebelum diberi layanan dan setelah diberi layanan konseling kelompok pendekatan RET teknik live model yang sebelumnya diperoleh rata-rata adalah 
120,42 , setelah dilakukan perlakuan nilai rata-rata nya menjadi 171,28. Hal ini menunjukkan bahwa nilai rata-rata mahasiswa yang diberikan layanan konseling kelompok pendekatan RET teknik live model lebih tinggi daripada nilai rata-rata mahasiswa yang belum diberikan layanan konseling kelompok pendekatan RET teknik live model.

\section{PENUTUP}

\section{Kesimpulan}

Dari hasil penelitian dapat disimpulkan bahwa ada pengaruh yang signifikan pemberian layanan konseling kelompok dengan pendekatan RET teknik live model terhadap tingkat kecemasan karir mahasiswa. Hasil perhitungan pada kelompok perlakuan diperoleh J $\mathrm{Jitung}=3$, dengan $\alpha=0,05$ dan $\mathrm{n}=7$, maka berdasarkan daftar, Jtabel $=2$. Dari data tersebut terlihat bahwa Jhitung lebih kecil dari Jtabel $(2<3)$. Karena J hitung lebih kecil dari $\mathbf{J}$ tabel, maka hipotesis $\mathrm{H} 0$ ditolak hal ini diperkuat dengan persamaan rumus $\mathrm{Z}$. Karena nilai z hitung adalah -2,52 dan itu lebih kecil dari nilai z tabel yaitu -1,96. Maka hipotesis ditolak artinya ada perbedaan antara sebelum dan sesudah diberi perlakuan sehingga tingkat kecemasan karir mahasiswa sesudah mengikuti layanan konseling kelompok dengan pendekatan RET teknik live model lebih rendah dari sebelum mengikuti layanan konseling kelompok dengan pendekatan RET teknik live model.

\section{Saran}

Adapun saran yang dapat dikemukakan penulis dalam penelitian ini adalah agar pihak Universitas lebih memperhatikan kecemasan karir yang dialami mahasiswa dengan cara mengadakan seminar-seminar ataupun pelatihan bagi para mahasiswa, agar para mahasiswa lebih dapat mempersiapkan diri menghadapi persaingan dalam dunia kerja.

Untuk para Dosen hendaknya memberikan beberapa informasi terkait dengan persiapan menghadapi dunia karir bagi mahasiswa BK disela-sela jam mengajar sehingga kecemasan karir yang dialai mahasiswa dapat berkurang.

Kepada peneliti lain yang menaruh perhatian untuk meneliti tentang kecemasan karir mahasiswa agar lebih memperhitungkan aspek-aspek lain yang memilki hubungan dengan masalah yang terjadi dilingkungan Universitas.

Untuk para mahasiswa hendaknya dapat meningkatkan kemampuan dirinya (soft skill maupun hard skill) agar mampu bersaing dengan para sarjana yang lain.

\section{DAFTAR PUSTAKA}

Adiphutra, Ngurah. (2015). Konseling Kelompok Perspektif dan Aplikasi. 
Yogyakarta : Media Akademi.

Andri, Yenny Dewi P. (2007). Anxiety Theory Based On Classic Psychoanalitic and Types of Defense Mechanism To Anxiety. Departemen Psikiatri Fakultas Kedokteran Universitas Indonesia, Jakarta.

Atkinson, R. L. Hielgard, Er. (1996). Pengantar Psikologi Jilid II. Jakarta : Erlangga

Carr, A. (2001). Abnormal Psychology. Philadelphia : Psychology Press

Chaplin, J. P. (1995). Kamus Lengkap Psikologi. Cetakan IV. Jakarta : PT. Raja Grafindo Persada.

Corey, Gerald. (2005). Teori dan Praktek Konseling dan Psiko Terapi. Bandung : Refika Aditama.

Fajar, Thomas. (2010). Hubungan Antara Kepercayaan Diri Dengan Kecemasan Dalam Menghadapi Dunia Kerja Pada Mahasiswa Semester Akhir Di Fakultas Psikologi Universitas Sanata Dharma Yogyakarta . Skripsi (Diterbitkan). Yogyakarta : Universitas Sanata Dharma

Greenberger, D \& Padesky, A.C. (1995). Manajemen Pikiran. Bandung :Kaifa.

Hanafi, (2007). Tingkat Kecemasan Hidup. Diakses pada tanggal 8 Agustus 2009 dari http://www.epsikologi.com

Hurlock, E. B. (1996). Psikologi Perkembangan. Jakarta : Erlangga

Hariono, R. (2000). Mengatasi Rasa Cemas. Gresik : Putra Pelajar.
Irham, M \& Novan Adri. (2014) Bimbingan dan Konseling Teori dan Aplikasi di Sekolah Dasar. Yogyakarta : Ar-Ruzz Media

Kartono, K. (1989). Kelainan-Kelainan Psikologi. Jakarta: Rajawali.

Kartono, K. (1992). Psikologi Wanita. Mengenal Wanita Sebagai Ibu \& Nenek.Cetakan. IV. Bandung : Mandar Maju

Kiswantoro, Arista . (2015). Model Bimbingan Kelompok Dengan Teknik Life Model Untuk Meningkatkan Rasa Percaya Diri Atlet Persinas Asad Kabupaten Kudus Tahun 2015. (Jurnal Konseling Gusgijang). Vol. 1, No. 2.Kudus : Program Studi Bimbingan dan Konseling FKIP Universitas Muria Kudus.

Kurnanto, Edi. (2013). Konseling Kelompok. Bandung; Alfabeta

Lumongga, Namora. (2011). Memahami Dasar-Dasar Konseling dalam Teori dan Praktik. Jakata : Kencana Prenada Media

Manrihu, Thayeb. (1988). Pengantar Bimbingan dan Konseling Karir. Jakarta : P2LPTK

Maramis, W. F. (1998). Catatan Ilmu Kedokteran Jiwa. Cetakan VII. Surabaya : Airlangga University Press.

Mopangga, F. 2005. Studi Deskriptif Kecemasan Terhadap Kematian Pada Para Aktivis Kesatuan Aksi Mahasiswa Muslim Indonesia (KAMMI). (Skripsi diterbitkan). Yogyakarta: Fakultas Psikologi Universitas Sanata Dharma Yogyakarta. 
Rahmasari, Andriani. (2016). Hubungan Persepsi Tentang Jurusan Bimbingan Penyuluhan Islam Uin Walisongo Semarang Dengan Kecemasan Karir. (Skripsi diterbitkan). Semarang : UIN Walisongo.
T. Bradley. (2016). 40 Teknik yang Harus Diketahui Setiap Konselor. Yogyakarta : Pustaka Pelajar.

Walgito, Bimo. (2010). Bimbingan + Konseling ( Studi dan karier). Yogyakarta : ANDI OFFSET 